\title{
Translating the Symbolic Hunting Series in Golding's Lord Of The Flies from English into Arabic: A Relevance-Theoretic Perspective
}

\author{
Khaled Al-Zu'bi (Corresponding author) \\ School of Humanities, Universiti Sains Malaysia, Malaysia \\ Aniswal Abdul-Ghani \\ School of Humanities, Universiti Sains Malaysia, Malaysia
}

Received: 27-02-2017

Accepted: 23-04-2017

Published: 30-04-2017

doi:10.7575/aiac.ijclts.v.5n.2p.39

URL: http://dx.doi.org/10.7575/aiac.ijclts.v.5n.2p.39

\begin{abstract}
This study comes as a response to the need for comparative assessment and evaluation studies of stylistic differences between English and Arabic in the field of literary translation in the Arab World. The main objective of this explanatory, analytical and comparative study was to investigate the translation of symbolism in William Golding's Lord Of The Flies (LOTF). The rich cultural connotations behind the employment of symbols in literary works constitute a great challenge to the literary translator. There is a need to ascertain the appropriateness of the translated symbols in the Arabic versions of LOTF. Two Arabic translations, Darweesh and Qaseh (2004) and Hamid (2002), are compared in terms of conveying the original symbolic style of the hunting series in LOTF. This study attempts to provide a relevance-theoretic account for the translation of symbols between English and Arabic. Relevance Theory (RT), as a communication theory which builds on a pragmatics, provides a way out of the traditional emphasis on the concept of the translation equivalence. It concentrates on the contextual environment of both the source language (SL) and the target language (TL) in achieving successful communication.
\end{abstract}

Keywords: Optimal Relevance, Cognitive Environment, Contextual Effects, Processing Efforts

\section{Introduction}

Literary texts usually employ various techniques to achieve their aims rhetorically and aesthetically (Katan, 2015). For example, literary men use figurative language to reflect their perspectives, views and styles of writing aesthetically and more effectively (cf. Al-Masri, 2010; Munassar, 2005). Being rife with figurative language, literary works constitute a challenge for translators (Tymoczko, 2016). This is due to the fact that figurative literary language, by its implicit connotative nature, does not express meanings and ideas in a direct way. Connotative layers of implicit meanings and associations, in addition to denotative direct meanings, are always present in the literary genre (cf. Bassnett, 2011; Traps, 2009).

William Golding's LOTF is a symbolic narrative that was published by Faber and Faber in 1954. Symbolism is a figure of speech that is employed by Golding in narrating LOTF. In addition to the semantic direct meanings of symbols, literary translators need to consider the implicit pragmatic and extra-lingual meanings and associations, which are usually dependent on cultural contexts, in the source language text (SLT) (cf. Zhonggang, 2006). In the present study, two Arabic translations, Darweesh and Qaseh (2004) and Hamid (2002), will be investigated in terms of conveying the original symbolic style in LOTF with regard to the series of hunting.

\section{Background of the Study}

Golding's Nobel-prized masterpiece has been translated into various languages for its significant universal themes and its skilful narrating style (Chaima, 2015). Since its first publication in 1954, LOTF has been translated into Arabic 10 times. It is an important work of art for which Golding was awarded the Nobel Prize in 1983. In fact, Golding's masterpiece mirrors his attitude towards the political situation in Europe during and after the period of World War II (Özçelik, 2015; Alnajm, 2015; Jeffares, 2002). LOTF reflects Golding's deep interest in mankind (Manzoor, 2007). Golding believes that "The shape of society depends on the ethical nature of the individual and not on any political system however apparently logical or respectable" (Baker \& Ziegler, 1988, p.16). He suggests that the welfare of people depends largely on the nature of every individual human being, which he believes to be evil. Calandra (1980) maintains that LOTF is symbolic by nature and that Golding has made a main contribution to man's self-awareness. Danicic (2012) summarizes the events and the themes of the novel in the following quotation,

LOTF describes how a group of British schoolboys fails to manage their life after having been evacuated in a deserted island. The aeroplane that was trying to rescue them from the devastating results of the war in which their country was involved has been shot down. The fall of the plane from the sky symbolises the fall of man from the state of innocence and the failure of civilization (p. 198). 
Symbolism is a figure of speech which indicates the use of symbols to represent ideas. Golding has employed symbolism in LOTF as a powerful mechanism in narrating social power relations (Gormez \& Dag, 2015; Bruns, 2009). By the heavy employment of symbolism in his narrative, Golding intends to effectively, though in an implicit way, influence the people of his time through displaying social power relations allegorically (Wilson, 2015). By following this specific writing style, i.e. the use of symbols to represent objects, ideas or people, Golding intends to motivate people to think about the inner evil inside them (Peter, 1988).

A symbol could be a person, an object or an event which refers to an idea or situation in real life. Many critics consider various events in LOTF as being symbolic as Golding bestows symbolic implications to many of the scenes in his narrative. His choice of words and descriptions are employed symbolically to serve the theme of his narrative. In this study, the researcher is going to analyse two Arabic translations of these events in order to shed light on the methods used by the Arab translators to convey the implied symbolic meanings. The researcher is going to focus on the extent to which the Arab translators succeed or fail in providing the TL readers with appropriate relevant translations. Translating symbols from English into Arabic implies a cultural transference of connotative meanings and associations (Sebotsa, 2016; Rafieyan et al., 2015).

\section{Translating Symbolism in Terms of Relevance Theory}

The main assumption of RT is the belief that communication presumes relevance. In other words, the addresser assumes that his intentions are worth the addressee's cognitive efforts and that utterances create expectations of their relevance. These exerted efforts always pursue relevance for the sake of achieving desirable contextual effects as the human cognition is geared to the maximisation of relevance (Wilson \& Sperber, 2002). This cognitive, psychological process succeeds only if the two ends of this equation, the exerted cognitive efforts and the achieved contextual effects, are considered by the addresser/translator (Gutt, 2000; Pilkingston, 2000).

RT is based on two principles of relevance, a cognitive principle and a communicative principle. The cognitive principle suggests that human cognition is geared to the maximisation of relevance. The communicative principle suggests that utterances create expectations of optimal relevance (Wilson \& Sperber, 2002). In other words, expectations of relevance of an utterance shall guide the hearer to derive the most appropriate meaning as the search for relevance is a main feature of man's cognition. Within the cognitive environment of the readers, the more contextual effects achieved the more relevant is an interpretation.

A relevance-theoretic based account of translation defines translation as a three-party interaction that includes the author, the translator and the target readers (Jing, 2010). When discovering the intentions of the author and then exploring the cognitive environment/context of SL and TL readers, the translator will be able to employ suitable methods and strategies in order to recreate the intended contextual effects of the original text. RT is concerned with familiarizing the readers in the TL with the intentions of the original author by introducing the original context of the ST for them. RT intensifies the importance of contextual information in terms of literary translation as a condition for achieving relevant translations (cf. Pegulescu, 2016). This task is usually accomplished by the translator/mediator through applying the direct or indirect translation strategies.

RT is significantly applicable in the fields of translation, stylistics and literary communication (Cruz, 2016). In terms of this theory, it can be said that the text of LOTF is said to be ostensive on the part of William Golding and inferential on the part of his audience (cf. Reza, 2016). According to RT, Gutt (2000), style in literary works can be translated properly by the application of two main approaches to translation: Direct and indirect translation (Pilkingston, 2000). According to the first approach, we can say that the poetic language implied in the use of symbolism in LOTF indicates what Gutt refers to as weak implicatures (Huang, 2011). These implicit meanings constitute Gutt's 'communicative clues'. These clues will lead the reader in the TL to the intentions of the original author. The translator is the one who is responsible for securing the most relevant meanings for the TL audience (Gutt, 2000). Gutt (1991) points out that,

A receptor language utterance is a direct translation of a source language utterance if and only if it purports to interpretively resemble the original completely in the context envisaged for the original (p. 163).

As to the quality of the translation, the yardstick is the TL readers' achievement of the intended meaning of the original as introduced by the translator, rather than the rules of equivalency suggested by traditional theories of translation. This can be achieved by the translator if his aim is to consider both the SLT and TLT as two interpretations of the author's thoughts. The interpretive resemblance between the SLT and TLT is important in making concrete comparisons between translation and original (Gutt, 1992). The extent of relevancy depends on the amount of the processing efforts and the achievement of the expected contextual effects (cf. Candria, 2011). Optimal relevance can be achieved by providing the TL audience with the most appropriate contextual effects without requiring them to exert any unnecessary cognitive processing efforts (cf. Shih, 2013).

\section{The Hunting Series in LOTF}

The hunting series in LOTF is considered an effective symbol for the bloody game of man's history (Baker \& Ziegler, 1988). Skilfully and symbolically, Golding describes how the hunts for food develop gradually into savagery. Dickson (1990) believes that through the series of hunts the boys are changing gradually into savages. According to Kelly (2011) the hunt represents violence and evil (Harris, 1970).

At the beginning of the novel, Golding describes the boys as being unable to kill an animal or even to see blood. They fail to kill a piglet in spite of the fact that it is an easy task for them since the pig is caught in creepers. Later, the boys 
are able to plan for hunting and it becomes easier for them to hunt, kill and cut flesh. At the end of the narrative, the boys are described as savages as they are now ready to kill themselves. The hunt series here represents the darkness of man's heart that leads him to eventually kill himself. Golding's symbolic description of these events requires the translators' consideration. Translators are required to convey Golding's intention behind depicting the boys' gradual degeneration symbolically. For achieving this aim they need to respect the original concise and subtle lexical choices of the author that represent his style of writing.

When the boys find a piglet "caught in a curtain of creepers" (LOTF, 51), Jack draws his knife and raises his arm in the air as a first step to attack the piglet. Golding says that after a while "the blade continued to flash at the end of a bony arm" (LOTF, 51). Skilfully, Golding describes both the weakness in Jack's arm and the presence of evil in the flashing of the blade. Describing Jack's arm as 'bony' indicates his weakness. Though, in describing the blade as flashing in Jack's arm, Golding foreshadows evil. Moreover, the verb 'continued' implies that the blade, in Jack's hand, stayed a relatively long time in the air, which is a clue that even Jack, the seemingly worst boy on the island, is not able to try to kill.

Soon after that, Golding provides the reason behind the boys' failure in killing the piglet before it runs away. He states that "The pause was only long enough for them to understand what an enormity the downward stroke would be" (LOTF, 51). This statement indicates that the boys are still innocent and humane. Then, Golding intensifies his view by clarifying the reason behind Jack's long waiting and inability to take the decision of killing by stating that, "They knew very well why he hadn't: because of the enormity of the knife descending and cutting into living flesh; because of the unbearable blood." (LOTF, 51).

In terms of the Arabic translations of these symbolic descriptions, the researcher believes that both translations fail to convey the appropriate implications and interpretations aimed by Golding's intention. For the first sentence which indicates both evil and weakness, the Arab translators convey the meanings in the following way:

SLT: the blade continued to flash at the end of a bony arm.

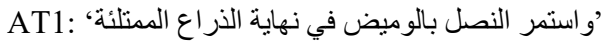

TRL: the blade continued to flash at the end of the plump arm.

G: [wastamara] [alnasslo] [bilwamedi] [fi] [nihayati] [althira،i] [almomtali’a]

AT2: 'واستمر التماع النصل عند نهاية الساعد الهزيلة'

TRL: the flashing of the blade continued at the end of the meagre forearm.

G: [wastamara] [iltima‘o] [alnasli] [‘inda] [nihayati] [alsa‘idi] [alhazila]

Darweesh and Qaseh implemented a literal translation procedure for securing the meaning of the above excerpt. The Arabic sentence 'واستمر النصل بالوميض is a successful literal translation as it preserves the symbolic intensification of the flashing of the blade which foreshadows evil to come in the following scenes. The transposition strategy which is followed by Hamid secures the meaning intended in the original text as well. Both translations are relevant to the TL audience.

However, for conveying the meaning in the other half of the excerpt, Darweesh and Qaseh, mistakenly, employ a modulation strategy by using the adjective 'المثنلئin' [almomtali'a] which means 'plump' as an equivalence to the original word 'bony' which means 'skinny'. They produce an irrelevant translation of the English adjective. A breakdown in communication occurs in this case as the Arab readers will not be able to elicit these symbolic nuances of meaning. Hamid's choice of an Arabic equivalent adjective is said to be a relevant translation. The Arabic word 'الهزيلة' [alhazilah] which means meagre conveys the original meaning.

Golding's choice of the word 'skinny' to describe Jack's arm aims at displaying the boy's weakness and inability to take the decision for killing a piglet. This view can be concluded from the context. It tells us that much time passes while Jack is raising his hand. Golding uses the word 'hiatus' to describe this relatively extended period of time. The Arab translators convey Golding's explanation for the abovementioned event as follows:

SLT: the pause was only long enough for them to understand what an enormity the downward stroke would be.

AT1: 'طال الصمت بشكل كاف بالنسبة لهم كي يدركوا هول ما ستؤول اليه الطعنة '

TRL: the silence prolonged enough for them to understand the horror the stab will result in.

G: [tala] [alsamto] [bishaklin] [kafi] [bilnisbati] [lahom] [kai] [yodriko] [ma] [sata'olo] [ilaihi] [altarnah]

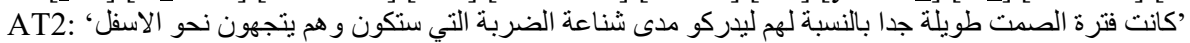

TRL: the period of silence was too long for them to understand the extent of the enormity of the blow that will occur while they are heading downwards.

G: [kanat] [fatrato] [alsamti] [tawilatan] [jidan] [bilnisbati] [lahom] [liyodriko] [mada] [shanaati] [aldarbati]

[allati] [satakono] [wahom] [yattajihon] [nahwa] [al'asfal]

Darweesh and Qaseh's interpretation and literal translation of the above sentence can be considered a successful one. They appropriately convey the intention of the original author which aims at explaining the reason behind the 'hiatus', i.e. the boys' fear of the act of killing a living thing or seeing its blood. Following the literal translation procedure secures a relevant translation in the TL.

On the other hand, Although Hamid's translation of the first excerpt can be considered more appropriate than the other translators', as he successfully conveys Golding's intention by using the word 'الهزيلة', which implies the aimed weakness that the original author intends, as an equivalent for 'skinny', his interpretation of Golding's explanation that follows cannot be considered an appropriate rendering of the original meaning. Hamid failed in construing the original 
author's intention. He translates only long enough as 'طويلة جدا' which means 'very long period of time', while Golding's intention is to refer to a short period of time which was enough for the boys to understand the consequences of what they may do. Moreover, Hamid, mistakenly, translate the downward stroke as ' which means that 'the boys were heading downward from a high place', while Golding means that the stroke is heading downward as Jack is raising his arm in the air. Hamid implemented a transposition translation procedure which fails to secure relevant translations to the audience in the TL.

To sum up, it can be said that the Arab translators fail to convey the original writer's intentions when he skilfully describes how the boys, specifically Jack who is considered the source of evil in the novel, fail in trying to kill a small animal. They, actually, require their audiences in the TL to exert unnecessary efforts for achieving undesired contextual effects. The translators' failure is due to the fact that they could not interpret the original author's symbolic intentions within the SL context or cognitive environment. They translated the aforementioned examples literally without any consideration of the symbolic meanings implied in the original text. The original author intends to describe how the boys degenerate gradually. In other words, he aims to intensify how the first attempt of killing is an unbearable experience for the boys. Accordingly, the Arabic translations are said to be irrelevant to the readers in the TL.

The second hunt attempt is described by Golding as a planned one. He describes Jack's professional movements, as he was trying to hunt a pig. Golding describes Jack's endeavour for hunting as follows, "He lowered his chin and stared at the traces as though he would force them to speak to him" (LOTF, 83):

SLT: He lowered his chin and stared at the traces as though he would force them to speak to him.

AT1: 'أحنى رأسه وحدق في هذه الآثار كأنه سيجبر ها على التحدث إليه

TRL: he bent his head and stared in these traces as if he is going to force them to speak to him.

G: [ahna] [ra'saho] [wahaddaqa] [fi] [hathihi] [alathar] [ka'naho] [sayojbiroha] [‘la] [attahadothi] [ilaih]

AT2: 'و أحنى ذقنه وبدأ بتعقب الآثار وكأنه يريدها أن تتحدث إليه

TRL: he bent his chin and started following the traces as if he wants them to speak to him.

G: [wa'hna] [thaqnaho] [wabada'a] [bita'qobi] [alathari] [waka'naho] [yoridoha] ['n] [tatahadatha] [ilayh]

Although Daweesh and Qaseh state that Jack 'أحنى رأسه' which means 'he bent his head', not his chin, their translation within the original context is an appropriate and successful one in comparison with Hamid's translation. The reason behind their success is that they convey the detailed description which reflects Jack's fascination with hunting. They translate 'as though he would force them to speak to him' as 'وكأنه سيجبر ها على التحدث اليه' which exactly reflects the meaningful intention of using the word 'force' by Golding. By translating Golding's selection of the word 'force' into 'يريد 'which means 'wants', Hamid failed to convey the purposeful intention of using the original word. Moreover, as described by Golding, Jack does not move or follow the traces in this scene, as indicated by Hamid's translation. Jack only stared at the traces while he was thinking of them. Accordingly, being irrelevant, Hamid's transposition translation procedure caused a communication failure in the TL.

Then in describing Jack's hair, Golding intends to mention how Jack's hair becomes much longer compared to its length at the beginning of the narrative when the boys were dropped on the island. Golding describes Jack's hair as follows, "His sandy hair, considerably longer than it had been when they dropped in, was lighter now" (LOTF, 84).

SLT: His sandy hair, considerably longer than it had been when they dropped in, was lighter now.

AT1: 'شعره الرملي أطول كثير ا مما كان عليه عندما نزلوا على هذه الجزيرة وصار لونه اكثف من ذب قبل فئل

TRL: his sandy hair much longer than it had been when they dropped in this island and its colour was lighter than before.

G: [sha‘roho] [alramli] [a’twalo] [kathíran] [mima] [kan] [‘alayhi] [‘indama] [nazalo] [‘ala] [hathihi] [aljazírati] [wasara] [lawnoho] [a'kshafa] [min] [thi] [qabl]

AT2: 'و اصبح شعره المغبر، الذي طال كثبر ا عندما وقعو ا على هذه الجزيرة، خفيفا

TRL: his dusty hair, which had become very long when they fell on this island, became lighter

G: [wa'śbaha] [sha‘roho] [almoghbaro] [allthi] [ㅁala] [kathiran] [‘indama] [waqa‘o] [‘ala] [hathihi] [aljazirati] [kafífan]

Darweesh and Qaseh's literal translation can be considered relevant to the readers in the TL as it conveys the symbolic evil implication of the long hair, i.e. its length. Reflecting the original implications, their translation states how Jack's hair becomes much longer than when they arrived at the island. Hamid, on the other hand, did not realize the symbolic importance of this comparison. Moreover, Hamid inappropriately mistranslated the word lighter which describes Jack's hair colour as 'خفيفا' which means 'little in density'. Golding could not have meant that Jack's red and tall hair, which is a symbol of evil, is little in density while Jack is becoming more and more degenerated. Accordingly, this latter translation, which follows a transposition translation procedure, is irrelevant to the readers in the TL.

In the same scene, Golding describes how Jack was looking for a clue to find a pig. He describes in detail how the droppings of a pig look like. In fact, this can also be considered a symbolic implication of the gradual degeneration of the boys, "The droppings were warm. They lay piled among turned earth. They were olive green, smooth, and they steamed a little" (LOTF, 85).

SLT: The droppings were warm. They lay piled among turned earth. They were olive green, smooth, and they steamed a little.

AT1: ' كان الروث دافئا وناعما ومتجمعا فوق الارض المقلوبة بلون أخضر زينوني، يتصاعد منه قليل من البخار

TRL: the dung was warm and smooth and grouped above the turned earth in an olive green colour and a little steam was rising from it. 
G: [kana] [arrawtho] [dafi'an] [wana،iman] [wamotajami‘an] [fawqa] [al'rdi] [almaqlobati] [bilawnin] [akdara]

[zaytoni] [yatasa‘ado] [minho] [qalilon] [min] [albokar]

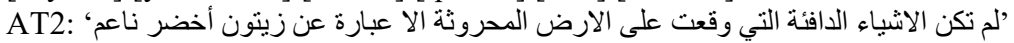

TRL: the warm things which fell on the ploughed earth were nothing but smooth green olives.

G: [lam] [takon] [al'shia'o] [aldafi'ato] [allati] [waqa‘at] [‘ala] [al'rdi] [almahrothati] [illa] [‘ibaratan] [‘n]

[zaytonin] [akdara] [naiim]

Darweesh and Qaseh convey Golding's description successfully by their literal translation. They realize Golding's intention with regard to describing the droppings in detail to reflect the extent of the state of degeneration of the boys, and to display how Jack becomes an expert hunter. On the other hand, Hamid distracted the audience in the TL from the intended meaning and context of the original text. He misunderstood the original text and came out with irrelevant translation. Hamid could not realize that Golding was describing, in details, the colour of the pigs' droppings and how they were steaming to emphasize the boys' degeneration. Hamid, mistakenly, referred to the olive plant fruits instead. Such a translation is totally irrelevant for the readers in the TL. More cognitive efforts will be exerted by the readership in the TL for undesirable contextual cognitive effects. Hence, Hamid's translation causes a total breakdown in communication in the TL.

The third hunt is a successful one as it is planned very well by Jack this time. He uses coloured clay to make masks for himself and his hunters as well. These masks remind us of camouflage in war. Jack describes it as being like 'dazzle paint'. These masks are not only used to help Jack and his tribe in hunting, they will also play a role in freeing them from humanity, shame and morals. It is a step towards total, moral degeneration, which symbolises the loss of ethical principles in real life which has led to the war in real life.

In describing how Jack is becoming more and more skilful in hunting, Golding gives an explanation with regard to how Jack is preparing to hunt professionally by making masks which will conceal him and his hunters from the sight of the pigs. Jack thinks that he could not have the opportunity to hunt a pig because pigs see rather than smell him. He explains “They don't smell me. They see me, I think. Something pink, under the trees.” (LOTF, 111)

SLT: They don't smell me. They see me, I think. Something pink, under the trees.

AT1: ' إنهم لن يشمو ار ائحتي. سيظنون أني شيء قرنفلي اللون تحت الاشجار'

TRL: They will not smell me. They will think that I am something pink in colour under the trees.

G: [innahom] [lan] [yashommo] [ra'ihati] [sayazonnona] [anni] [shai'on] [qoronfuli] [allawni] [tahta] [al'shjarar]

AT2: 'إنها لا تشني، بل تراني، هذا ما أعتقده. ثمة شيء هناك وردي اللون تحت الاشجار'

TRL: They do not smell me. They see me. This is what I think. There is something pink in colour under the trees.

G: [innaha] [la ] [tashommoni] [bal] [tarani] [hatha] [ma] [a،taqidoh] [thammata] [shai'on] [honaka] [wardio]

[allawnni] [tahta] [alashjar]

Darweesh and Qaseh's translation can be considered successful in spite of the fact that they did not translate, explicitly, one of the sentences in the extract above. Their translation, by following a transposition procedure, reflects Jack's thinking as intended by Golding. On the other hand, Hamid failed to convey the meaning of Jack's words as he mistranslates the last sentence. His last sentence means that Jack suddenly saw something under the trees, which is invalid. Hence, Hamid's translation, contrary to Darweesh and Qaseh's translation, can be considered irrelevant to the audience in the TL.

After the previous hunt attempt, the relationship between the two main characters, Ralph and Jack, is about to break up as Jack is totally indulged in hunting and does not give a hand in building the shelters or watching the signal fire, which are more important issues in Ralph's opinion. Now, when Jack and his hunters succeed in killing a pig as they plan well for it, a gap between two camps led by Ralph and Jack starts to surface. The direct reason behind this divide is that a chance for rescue is lost when the signal fire dies as Jack takes the boys, who are supposed to be responsible for keeping it alight, to help him in hunting. Now, evil starts to spread on the island and most of the boys are going to, gradually, lose their humanity and turn into savages.

In the next hunting attempt, which is an unplanned one, Ralph participates and hit a pig with his spear but fails to catch. In this scene, Jack is described as he loves the droppings of these animals (LOTF, 205), which implies the extent to which degeneration overwhelmed the boys.

After that, Jack split from Ralph's group and make his own tribe. Many of the boys join him gradually. Now, he moves to the Castle Rock, a rocky place at the other end of the island, and make that location his tribe's fort. But before accomplishing this goal, he planned for a new hunt. This hunt is actually the cruellest and most savage. The prey, this time, is a mother pig. This time, Jack offers the head of the sow as a gift for the beast. The boys make a party and dance in circles after the feast. Primitiveness and degeneration are spreading fast everywhere on the island. These actions show that the boys are now primitive, underdeveloped and cruel savages (cf. Firth, 2011). After this hunt, the boys become totally savages. They kill Simon and then Piggy. Evil is now everywhere on the island.

At the beginning of this hunt, Jack is described as looking for the droppings of pigs. However, the Arab translators fail to communicate the intention of the author who tries to describe Jack's extreme degeneration. Golding states that "Almost at once Jack found the dung and scattered roots that told of pig" (LOTF, 249). The Arab translators translate this statement as follows:

SLT: Almost at once, Jack found the dung and scattered roots that told of pig 
AT1: 'وسر عان ما وجد جاك آثار حو افر وجذور مبعثرة تدل على وجود خنزير'

TRL: Soon, Jack found traces of hoofs and scattered roots which indicate the presence of pigs.

G: [wasor‘an] [ma] [wajada] [jak] [athara] [hawafira] [wajothoran] [moba،tharatan] [tadolo] [‘ala] [wojodi]

[kinziri]

AT2: 'على الفور عثر جالك على حفرة وجذور مبعثرة مما يدل على وجود خنزير '

TRL: Jack immediately found the hole and scattered roots, which indicates the presence of pig

G: ['alal] [fawri] ['athara] [jak] [‘ala] [hofratin] [wajothorin] [moba،tharatin] [mima] [yadolo] ['ala] [wojodi]

[kinzir]

Both Arabic translations disregarded the word 'dung', which means 'the droppings of animals'. This word, as mentioned earlier, is a symbol of degeneration. It is very important to refer to this word in the Arabic translation as Golding intends to use this very word, but not the word 'droppings' for example. He intends to let the reader feels the gradual moral degeneration of the boys, which is representing the actual people's degeneration in the real world. The Arab translators did not translate this word into Arabic. Darweesh and Qaseh used the word ' فورو [ [hawafir], which means 'hoofs', instead. This makes their translations irrelevant to the Arab readers. Hamid, on the other hand, used the word 'حفرة ' implemented wrongly by the Arab translators, has failed to secure relevant Arabic translations in the TL. It is worth noting that Golding named the remains of the pigs as 'droppings' in the scene preceding this one. Here, he uses the word dung explicitly to refer to the same object, the droppings of animals.

Later, Golding describes Jack as wearing darkness, "He was happy and wore the damp darkness of the forest like his old clothes" (LOTF, 250). In fact, Golding is very careful in choosing his words. Clearly, he states that it was Jack who wore the darkness of the forest instead of his old clothes. Jack is described as being a source of evil throughout the narrative. Accordingly, Golding intends to describe him as being happy to wear darkness instead of his clothes.

SLT: He was happy and wore the damp darkness of the forest like his old clothes.

AT1: 'كان سعيدا ويلفه الظلام القاتم للغابة كما تلفه ملابسه القديمة '

TRL: he was happy and shrouded in the darkness of the forest as his old clothes do.

G: [kan] [sa‘idan] [wayalofoho] [azalamo] [alqatimo] [lilghabati] [kama] [taloffoho] [malabisoho] [alqadima]

AT2: 'كان سعيدا وقد ارتدى ظلمة الغابة الرطبة كأنها من ملابسه القديمة [ave

TRL: He was happy to have worn the darkness of the humid forest as if it is part of his old clothes.

G: [kan] [sa‘idan] [waqad] [irtada] [zolmata] [alghabati] [arratibati] [ka’nnaha] [min] [malabisihi] [alqadima]

Darweesh and Qaseh realize Golding's intention and described Jack as standing happily in the dark forest. Their translation informs the reader in the TL of the original symbolic metaphor. Golding describes Jack as wearing darkness instead of his clothes which represent civilization. Their literal translation secures relevance in the TL. On the other hand, Hamid's translation, by following the transposition procedure, sounds less relevant as it adds some irrelevant meaning to the original text, which may distract the reader for undesirable contextual effects.

After that hunt, in a primitive ceremonial tribal behaviour, Jack offers the head of the pig to the unknown beast as a gift. Jack says, "This head is for the beast. It is a gift" (LOTF, 256). The Arab translators convey the meaning of this gift in two different ways. Darweesh and Qaseh translate the word gift as 'قربان' [qorban], an offering for religious purposes. This Arabic equivalence, which they have chosen depending on the context in the scene, seems irrelevant. Hamid use the literal translation of the English word 'هدية' [hadiyah]. Although the Arabic word 'قربان' has a religious implication as it refers to Adam and Eve's gift for Allah, the researcher believes that, by using the word 'gift', the original author does not intend to imply this religious meaning. He only aims to cover the idea from the boy's perspective. Accordingly, the literal translation of the word sounds more relevant for the audience in the TL.

The scene of killing the mother sow is symbolically a sexual one (Baker \& Ziegler, 1988). The fact that the boys are killing a mother sow while she was taking care of her young piglets symbolises destroying the future. Golding describes the boys as being "wedded to her in lust" (LOTF, 252). Golding aims to symbolically refer to the Oedipadian wedding night (ibid.). This implication indicates how savage and degenerated the boys become.

The Arab translators cover the intention of the original author, partially, in their translations. Their audience cannot discover the sexual symbolic reference through the literal translations of the SLT:

SLT: and the hunters followed, wedded to her in lust (LOTF, 252)

AT1: 'و الصيادون يلحقون بها، منشدين اليها بشهوة جامحة 'و

TRL: and the hunters are following her, captured by her in an unbridled lust.

G: [wassayyadona] [yalhaqona] [biha] [monshaddina] [iliha] [bishahwatin] [jamiha]

AT2: 'تبعها الصيادون تشدهم اللهفة

TRL: the hunters followed her captured by eagerness.

$\mathrm{G}$ : [tabi،aha] [alsayyadona] [tashoddohom] [allahfa]

Darweesh and Qaseh's literal translation to the sexual implication of the expression wedded to her in lust into ' 'اليها بشهوة جامحة ' can be considered appropriate as it refers implicitly to the sexual desire aimed by the original text. This means that their translation is relevant to their audience in the TL. On the other hand, Hamid failed to refer to this connotative meaning in his translation. His translation 'تشدهم اللهفة' does not contain any sexual implication and, hence, deprive the readers in the TL from the intention of the original author.

The last hunt in the narrative is the cruellest one. This time, the boys are hunting a human being. They intend to kill Ralph, their leader. The boys become real cruel inhumane savages. They act like primitive, barbarian and brutal people. 
They finally burn the whole island in order to find and kill Ralph. Fortunately, and ironically, he is saved by a naval officer, who is armed and involved in a real war in the world of adults. Golding is referring here to the impossibility of real relief, as man is according to him, evil by nature.

To sum up, the researcher has analysed the translations of the symbols employed in conveying the implications of the hunting series in LOTF. The analysis has been based on the principles and concepts of RT. The analyses of the Arabic translations of the symbols in this study prove the researcher's hypothesis with regard to the possibility of breakdown in communication in terms of the Arabic translations. The Arab translators involved in this research have not succeeded, in many cases, to secure relevant translations or interpretations of the original symbols, as employed in the original text, for their readers in the TL. Their failure in maintaining symbolism in the TL makes their translations partially irrelevant for the readers in the TL in many cases. The Arab translators' ignorance of the symbolic value of the novel, their commitment to the traditional theories and strategies of translation and their inability to realize the existence of some symbols in the original text are the main reasons behind the shortcomings in their translations.

The Arab translators have followed various translation procedures in order to convey the meanings of symbols in LOTF. It seems that they are not aware of the symbolic value of the narrative. In spite of this tendency, some of their translations are considered successful. Some of the traditional translation approaches and procedures followed by the Arab translators are likely to secure appropriate translation if the principles of RT are taken into consideration. Actually, Gutt declares that all translation procedures could work under the umbrella of RT. The most employed translation procedures implemented by the Arab translators are: literal translation, transposition, modulation, borrowing, calque, omission, equivalence and adaptation (Vinay \& Darbelnet, 1995).

\section{Conclusion}

A symbol in a literary work implies layers of meaning. The role of the translator according to RT is to reproduce these implicit meanings in the cognitive environment of the target reader. Recognizing the author's intention of employing a symbol is very important for the achievement of successful communication. The relevance-theoretic concepts such as optimal relevance, cognitive environment, contextual effects and processing efforts are very important for the translator to arrive at the intentions of the author and to accomplish appropriate relevant translations.

\section{References}

Al-Masri, H. (2010). The Difficulty in Translating Modern Arabic Literature for the Modern World: Reconsidering the Work of Translation from a Semiotic Perspective. Lewiston: Edwin Mellen Press.

Alnajm, A. L. (2015). "The main themes in Lord of the Flies." International Journal of English and Literature 6 (6): 98-102.

Baker S. \& Ziegler, M. (1988) (Eds.) [1988]. William Golding's Lord of the Flies: Text, Notes and Criticism. New York: Penguin.

Bassnett, S. (2011). Reflections on Translation. Tonawanda, NY: Multilingual Matters.

Bruns, B. (2009). "The Symbolism of Power in William Golding's Lord of the Flies." Sweden: Karlstad University.

Calandra, D. (1980). Lord of the Flies Notes. London: C. K. Hillegass.

Candria, M. (2011). "The Value of Relevance Theory in Literary Analysis." In Prosiding Seminar Nasional: Membangun Masyarakat Indonesia Dalam Perspektif Budaya (pp. 197-213). Fakultas Ilmu Budaya, UNDIP, Semarang.

Chaima, S. (2015). Symbolism in William Golding's Novel Lord of the Flies (1954) (Doctoral dissertation, University Of Mohamed Kheider Biskra).

Cruz, M. P. (2016). Some Directions for Future Research in Relevance-theoretic Pragmatics. Relevance Theory: Recent Developments, Current Challenges and Future Directions, 268, 307.

Danicic, M. (2012). Biblical Symbolism Of The Plot And Characters In William Golding's Novel Lord of the Flies. (Ph.D. Dissertation, University of Belgrade).

Darwish, A. and Qaseh, Q. (2004). Sayyed Al-Thubab. Damascus, Osama Publishing.

Firth, R. (2011). Symbols: Private and Public. Oxon: Routledge .

Goldings, W. (1954). Lord of the Flies. Beirut: Librairie du Liban.

Görmez, A., and Dag, S (2015). "Struggle for Power in Macbeth and Lord of the Flies." Gazi Üniversitesi Sosyal Bilimler Dergisi 2(4).

Gutt, E. A. (1991). Relevance. Cambridge: Basil Blackwell.

Gutt, E. A. (1992). Relevance Theory: A guide to Successful Communication in Translation. Dallas: Summer Institute of Linguistics.

Gutt, E. A. (2000). "Translation as Interlingual Interpretive Use". The translation Studies Reader.

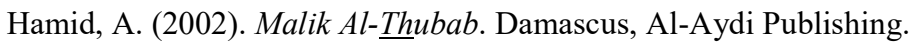

Harris, J. R. (1970). Allegory and Symbol in the Novels of William Golding. (MA Thesis). Open Access Dissertations and Theses. Paper 5060. 
Huang, X. (2011). Stylistic approaches to literary translation: with particular reference to English-Chinese and Chinese-English translation (Doctoral dissertation, The University of Birmingham).

Jeffares, A. N. (2002). William Goding's Lord of the Flies. Beirut: Librairie du Liban Publishers.

Jing, H. (2010). The Translation of English and Chinese Puns from the Perspective of Relevance Theory. The Journal of Specialised Translation, 13, 81-99.

Katan, D. (2015). Translating the "literary" in literary translation in practice. Lingue e Linguaggi 14, 7-29.

Kelly, M. (2011). Cliffs Notes on Golding's Lord of the Flies. Houghton Mifflin Harcourt.

Manzoor, S. (2007). "The Prometheus Myth in the Novels of William Golding". BRAC.

Munassar, A. A. (2005). Theoretical Perspectives on the Difficulty of Literary Translation:Rhetorical Images in Orwell's Animal Farm. (Doctoral dissertation, Université d'Alger, Algeria).

Özçelik, K. (2015).The Effects Of Totalitarianism As Reflected In William Golding's Lord Of The Flies, George Orwell's Animal Farm And Nineteen Eighty-Four. (MA Thesis). Atilim University.

Pegulescu, A. M. (2016). Is Relevance Theory Applicable to Proverbs' Translation?. Journal of Language and Cultural Education, 4(1), 124-132.

Peter, J. (1988). "The Fables of William Golding." In James R. Baker \& Arthur P. Ziegler, Jr. (Eds) William Golding's Lord of the Flies: Text, Notes and Criticism. Penguin.

Pilkingston, A. (2000). "Poetic effects: A relevance theory perspective" (Vol. 75). John Benjamins Publishing.

Rafieyan, V., Behnammohammadian, N., and Orang, M. (2015). "Relationship between Acculturation Attitude and Pragmatic Comprehension." Journal of Language Teaching and Research, 6(3): 504-512.

Reza, A. (2016). Intentionality and Conventionality in the Use of Irony (MA Thesis, University of Warsaw).

Sebotsa, M. (2016). "Translating extra-linguistic culture-bound concepts in Mofolo: a daunting challenge to literary translators." Tydskrif vir letterkunde 53(2): 105-116.

Shih, C. L. (2013). "Subjectivity Identification: A Case Study of Chinese-to-English Translation of Hakka Proverbs." International Journal of English Linguistics, 3(5): 38.

Traps, Y. (2009). "Representing the Translator: Making Sense of Translation in Cross-Language Qualitative Research." Graduate Journal of Social Science, 6 (3), 142-147.

Tymoczko, M. (2016). Translation in a Postcolonial Context: Early Irish Literature in English Translation. Routledge.

Vinay, J. P., and Darbelnet, J. (1995). Comparative stylistics of French and English: A Methodology for Translation. John Benjamins Publishing.

Wilson, E. (2015). "Warring Sovereigns and Mimetic Rivals: On Scapegoats and Political Crisis in William Golding's Lord of the Flies." Law and Humanities, 8(2), 147-173.

Wilson, D., \& Sperber, D. (2002). Truthfulness and relevance. Mind, 111(443), 583-632.

Zhonggang, S. (2006). "A Relevance Theory Perspective on Translating the Implicit Information in Literary Texts." Journal of Translation, 2 (2): 43-60. 